\title{
住宅地街路の夜間光環境評価と住宅外構照明の関係 \\ THE RELATIONSHIPS BETWEEN THE EVALUATION OF LIGHTING ENVIRONMENT ON NIGHTTIME RESIDENTIAL STREETS AND HOUSE EXTERIOR LIGHTING
}

\author{
村 松 陸 雄*, 中村 芳 樹**, 中島 政太郎***, 小林茂 雄**** \\ Rikuo MURAMATSU, Yoshiki NAKAMURA, Seitaroh NAKAJIMA \\ and Shigeo KOBA YASHI
}

\begin{abstract}
This study examined to know how the function of house exterior lighting, especially gate lighting, porch lighting and ornament lighting, for the evaluation of lighting environment on the nighttime residential streets. An experiment using a real residential street, where people actually live, was carried out. The results suggested that the evaluation of lighting environment can be improved not only by the amount of light but by the light fittings attached on the gate or at the porch or on the hedge. Moreover, house exterior lighting can indicate the personality of the owner.
\end{abstract}

Keywords: Lighting Environment, Residential Street, House Exterior Lighting 光環境、住宅地街路、住宅外構照明

1. 研究の背景

人類が光を発見して以来、私たちの生活は多様な光環境の機能を 配慮することで豊かなものとなってきた。先達たちがこれまで考虑 してきた光環境の機能としては、主として、以下に示す二つの機能 に大別できる。

第一に、光環境の「明視性」りとしての機能である。これは、ある 行為を行うことを想定したときにその行為を遂行する上での必要条 件としての光環境を提供することである。例えば、読書をするとき の文字の見え方から最適な机上面照度を導出したり 2)、光環境の不 快グレアを抑制することで、VDT 作業時にも不都合を感じないオ フィス環境が実現できる31。

第二に、光環境の「心理的効果」としての機能である。この「心 理的効果」は、「直接的な心理的効果」と「間接的な心理的効果」に さらに小分類される。「直接的な心理的効果」としては、人間と光環 境との関係性に扔いて、光環境が直接的に人間の認知メカニズムに 働きかける心理的な効果を意味する。例えば、空間全体の輝度分布 を考虑することで空間からの明るさの印象(例えば、明るさ感)を 操作できる。さらに、空間の用途に応じた光環境を演出することで、 人間は空間の場所性にふさわしい雾囲気を知覚するら。一方で、「間 接的な心理的効果」は、光環境による空間評価への間接的な効果の
ことを指す。換言すると、まず、光環境が空間評価には直接関係の ない概念に影響及ほし、次の段階として、その変容した概念が媒介 変数的‘注〉!に㞬間評価に影響するのである。光環境が「間接的な 心理効果」を与える例としては、フランスのロマネスク教会の光環 境が挙げられる。架間全体が暗いなかで祭壇の上部にある大きなス テンドグラスのみを輝かせることが、教会の中にいる信徒に黒く見 える祭壇ごしに入射する光を仰がせ、そのことが光を神の隠喻的な 意味として信徒に強く印象づけることになるあ。さらに、媒介变数 的に光を神の隠喻的な意味を感じさせることが、教会の光環境の総 合的な評価を肯定的に規定していると考えられる。

さて、実務的な照明設計の場面を考えてみると、上記の「明視性」 と「直接的な心理的効果」を考慮することはあっても、「間接的な 心理効果」を積極的に配慮した照明設計の事例はほとんど見当たら ない。本報は、光環境による「間接的な心理効果」、特に、光環境 の「間接的な心理効果」としての機能を実際の照明計画への適用す ることの可能性を探ることを目的とする。具体的に研究対象として は、住宅地街路の照明計画を取り上げる。その理由として、住宅地 街路のような屋外空間では屋内空間に比べて光環境の「明視性」が それほど重要視されないことから相対的に光環境の「間接的な心理 効果」による影響が強まると考えられることと、住宅地街路は街路

\footnotetext{
* 東京工業大学大学院人間環境システム尃攻 大学院生・修士: (社会学), M. Sc

** 東京工業大学·大学院人間環境システム尃攻 助教授・博上 (“学)

*** 西松建設侏) 修士: (工学)

**** 東京工業大学大学院人間環境システム専攻 助手. 博 t: ( 工学)
}

Graduate Student, Tokyo Institute of Technology, M. Soc., M. Sc.

Assoc. Prof., Tokyo Institute of Technology, Dr. Eng.

Nishimatsu Corp., M. Eng.

Research Assoc., Tokyo Institute of Technology, Dr. Eng. 
という公的領域と住宅という私的領域が隣接した空間であり、公私の関倸性からの「間接的な心理効果」が光環境の評価に有意に影 響を及ぼすことが考えられるからである。

住宅地街路における照明に関する既往研究で、自動車を安全に運 転する上での安全性に基づいた所要照明条件》や防犯上から街路照 明の要件7的的いが明らかにされている。例えば、JIS 道路照明基準 (Z9111) 光は、道路上の障害物や道路の状態の識別性に基づいて、路 面の水平面照度や人の顔の高さ $(1.5 \mathrm{~m})$ での鉛直面照度の基準照度が 定められている。宮前らは1は、4 $\mathrm{m}$ 前方の人物の顔の視認性を満た す照明条件を実験による手法により検討し、顔面の位置における鉛 直面照度が約 $21 x$ 以上必要であることを示している。これらの研究 は、先に筆者らが分類した「明梘性」の観点から光環境の機能を配 慮しており、本研究で焦点を当てる光環境の「間接的な心理効果」 には言及していない。

また、鹿倉ら ${ }^{21}$ は住宅地街路のコンピュータグラフィックス(CG) を用いた主観印象評価実験の結果として、夜間の街路照明環境から の印象を”明るさ”、"均一さ”、"快適さ”の3つのグループに分類 し、その内の”明るさ”と”均一さ”は水平面照度と鉛直面照度と 相関が高いことを明らかにしている。この研究では、住宅地街路の 光環境を構成する照明要素として街路灯のみに限定して検討してお り、本報で検討した住宅地の門灯、玄関灯等については触れられて おらず、さらに、光環境による印象についても、先に筆者らが分類 した「直接的な心理効果」に終始しており、「間接的な心理効果」に 踏み込んで検討されていない。

本研究の主題は、光環境の「間接的な心理効果」の機能を実際的 な照明計画に適用することの可能性を探ることであり、特に私的領 域に属する住宅の照明要素、具体的には、門灯や立関灯などによる 「間接的な心理効果」が、公的領域である住宅地街路の光環境の評価 に及ほす影響を明らかにすることである。公的領域と私的領域の関 係からの関連研究としては、Newman ${ }^{13}$ による建築空間と防犯性に 関する研究がある。彼は、建築空間のしつらえを考慮することが住 民によるテリトリー意識と自然監視性を高めることになり、その結 果として、犯罪の発生を抑制できることを明らかにした。この研究 を端緹にして、わが国でも多くの研究が141151去、犯罪に対する不安 感と建築灴間の構成との関係について検討し、Newmanの知見を確 認し、さらにそのための具体的な方策について明らかにしている。 例之ば、友田 ${ }^{15}$ |は、私的領域にある住宅を公的領域もしくは共有領 域に開放させることがテリトリー意識を高めることにつながること を示している。この研究は、建築空間の構成とテリトリー意識の形 成過程についての有益な示唆を与えているが、私的領域の照明（例 えば、門灯、玄関灯等）の機能についてふれておらず、さらに、そ の機能とこれまで主として考慮されてきた公的領域における照明 (例えば、街路灯等)の機能との関係性については検討していない。 本研究では、住宅地街路の夜間光環境の構成要素のうち、街路に 設置された街路灯、住宅外構照明としての門灯や玄関灯、玄関ポー チの植栽の上に設置した電飾照明を考える。光環境は、公的領域の 光環境と私的領域の光環境の構成要素に分けて考えることができる。 公的領域における光環境の構成要素としては、街路に設置された街 路灯が挙げられ、一方、私的領域の光環境の構成要素には、住宅外 構照明としての門灯や玄関灯、住宅の空を通しての室内からの漏れ
光等が考えられる。そのうち空からの漏れ光は、重要な要素と考え られるものの、住民の住まい方に強く依存して変わりうるものであ り、研究の主目的が私的領域に属する光環境の機能を公的領域にお ける実際的な照明計画の中に積極的に導入することを提案すること であるから、今回の検討から除外した。

2. 研究の方法

夜間住宅地の街路空間における私的領域に属する住宅の照明要素、 具体的には、門灯や玄関灯などによる「間接的な心理効果」が、公 的領域である住宅地街路の光環境の評価に及ほす影響を明らかにす ることを目的として、実際の住宅地を用いた操作実験を行った。本 実験で用いた住宅地は、東京のベッドタウンとして位置づけられる 多摩エリアにある1970年代に私鉄系の民間不動産会社の主導により 開発された住宅地である。

操作した実験変数は、街路灯の照度レベル（高照度、中照度、低 照度）、門灯（あり、なし）、立関灯（あり、なし）、電飾照明（あ り、なし)である（表 1)。街路灯の照度レベルの設定について、高 照度レベルはJIS 道路照明基準に準じ、中照度レベルは一般的な住 宅地街路照明を、低照度レベルは街路照明がない場合を想定した。 街路灯の照度レベルの調光方法としては、既設の街路灯に減光させ るためのフィルタを付加させることで行った（写真 1 )。電飾照明 は、クリスマスの演出用に市販されている豆電球が70個連結され ているもので点滅機能があるものを用い、玄関ポーチにある植栽の 上に設置した。

\section{表 1 操作変数の一覧}

\begin{tabular}{|c|c|c|c|}
\hline 街路灯照度レベル & 門灯 & 玄関灯 & 電飾照明 \\
\hline $\begin{array}{l}\text { 高照度(水平面照度約3.01x) } \\
\text { 中照度(水平面照度約0.61x) } \\
\text { 低照度(水平面照度約0.21x) }\end{array}$ & あり & なし & なし \\
あり & あり \\
\hline
\end{tabular}

注）街路灯照度レベルは道路部分の平均水平面照度

被験者は、奏験変数を操作した 7 戸の住宅が全視野に入る位置 （図 1 の観察点）に静止し、(1) 環境に関する評価項目（"不安感を 感じる”、”明るさ感がある”、”人の気配を感じる”、”監視性が高 い”）、(2)住民のパーソナリティを推測させる質問項目（"社交的で ある”、”家族の仲が良い”、”親しみがある”、”誠実で信頼できる”、” 独自性がある゙)、についてそれぞれ7件法により回答させた。環境 に関する評価項目の質問は、先に言及したNewman と彼の知見を精 緻に検討したその後の研究者の知見と、筆者らが本研究に先立ち実

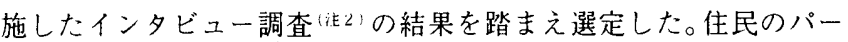
ソナリティを推測させる質問項目の選定については、社会心理学の 対人認知の研究で用いられている質問項目(6)に基づいて著者らが独 自に作成した。住民のパーソナリティに関する質問において評価の 対象とした住民は、図1における住宅Cの住民である。写真 2 に実 験の梯子を示す。被験者は 20 代の男性 10 名、女性 8 名の計 18 名とした。 


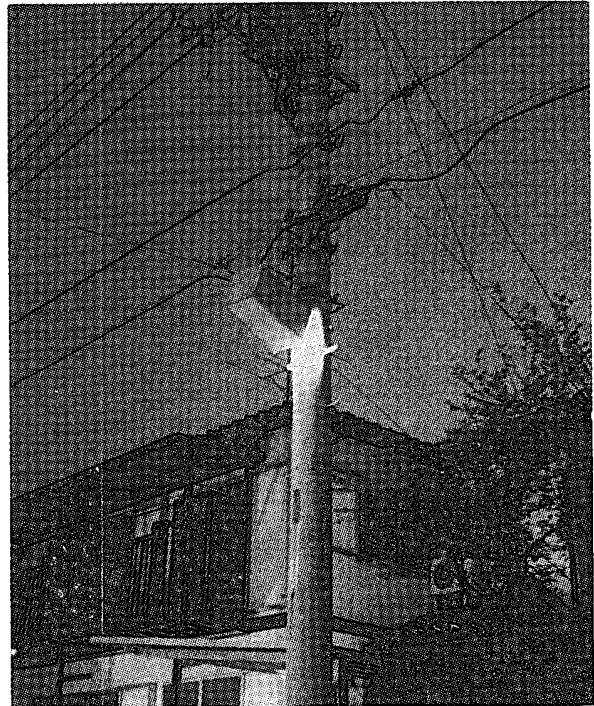

写真 1 街路灯の減光方法

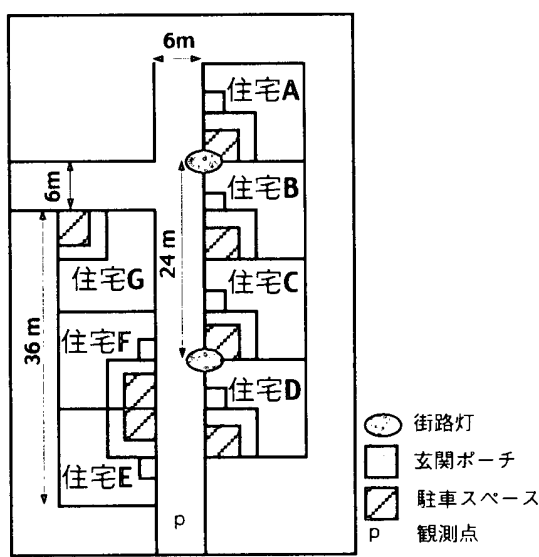

図 1 実験に用いた住宅地の概要

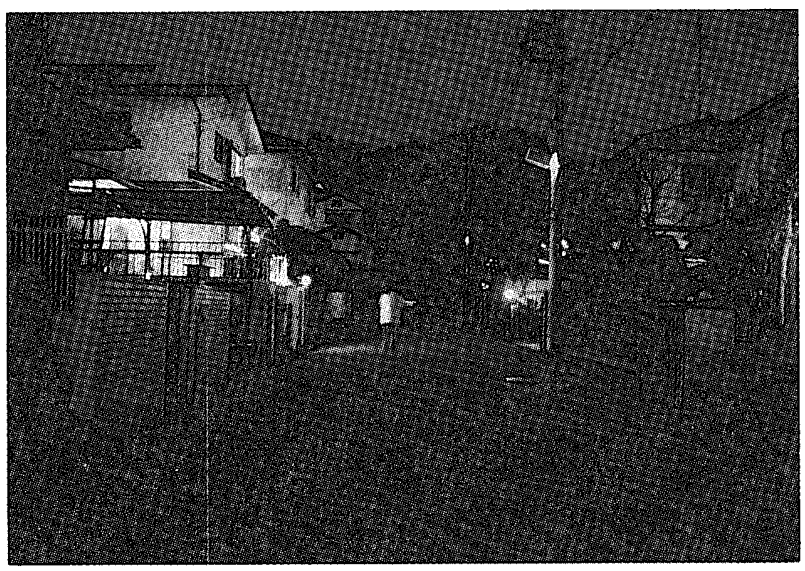

写真 2 実験に用いた住宅地

3 . 結果

環境に関する評価項目

表 2 に環境に関する評価項目（"不安感を感じる”、”明るさ感が ある”、”人気配を感じる”、”監視性が高い”）に関する実験結果を 示す。全 7 戸の住宅の門灯・玄関灯が消灯している照明手法 (以下、 【All off】と呼ぶ）を比較群として、全 7 戸の住宅のうち 3 戸におけ る門灯・玄関灯が点灯しそれ以外の 4 戸の門灯・玄関灯が消灯して いる照明手法（以下、【3/7 on】と呼ぶ）、全 7 戸の住宅招ける門灯.
玄関灯が点灯している照明手法 (以下、【All on】と呼ぶ)、立関ポー チにある植栽の上に設置に電飾灯が付加された照明手法(以下、【電 飾照明】と呼ぶ）の三つの照明手法ごとの影響の違いを 1 元配置分 散分析(ANOVA)により検討した。表中の数值は全被験者による評価 の平均値を示し、数值のレンジは最大値の 7 から最小值の 1 で、大 きい数値ほど評価項目についての否定的な傾向を意味する。

街路灯の照度レベルが高照度の条件で、【All on】の照明手法の場 合に”不安感を感じる”と”明るさ感がある”の質問項目で危険水 準 5\%で有意差があり、”の気配を感じる”の質問項目で危険水準 1\%で有意差が示された。”監視性が高い”についての質問項目は有 意な違いは見られなかった。【電飾照明】の照明手法の場合に”不安 感を感じる”、”明るさ感がある”、”人の気配を感じる”の質問項目 で危険水準 1\%で有意差があった。”監視性が高い”についての質問 項目は【3/7 on】、【All on】、【電飾照明】のいずれの照明手法の場合 にも有意な違いは見られなかった。

街路灯の照度レベルが中照度の条件で、【3/7 on】の照明手法の場 合に”不安感を感じる”と”明るさ感がある”の質問項目で危険水 準 1\%で有意差があり、”人の気配を感じる”の質問項目で危険水準 5\%で有意差が示された。【All on】の照明手法の場合に”不安感を 感じる”の質問項目で危険水準 5\%で有意差が示された。電飾照明】 の照明手法の場合に”不安感を感じる”、”明るさ感がある”、”人 気配を感じる”の質問項目で危険水準 $1 \%$ で有意差があった。”監視 性が高い”についての質問項目は【3/7 on】、【All on】、【電飾照明】 のいずれの照明手法の場合にも有意な違いは見られなかった。

街路灯の照度レベルが低照度の条件で、【All on】の照明手法の場 合に”不安感を感じる”と”人の気配を感じる”の質問項目で危険 水準 $1 \%$ で有意差があり、”明るさ感がある”の質問項目で危険水準 $5 \%$ で有意差が示された。【電飾照明】の照明手法の場合に”不安感 を感じる”、”明るさ感がある”、”人気配を感じる”の質問項目で 危険水準 1\%で有意差があった”監視性が高い”についての質問項

\section{表 2 環境に関する評価項目に関する実験結果}

\begin{tabular}{|c|c|c|c|c|}
\hline \multicolumn{5}{|c|}{ 街路灯照度レベル（高） } \\
\hline & All off & $3 / 7$ on & All on & 電飾照明 \\
\hline 不安感 & 3.89 & 4.17 & $2.94^{*}$ & $1.78^{* *}$ \\
\hline 明るさ感 & 4.06 & 3.67 & $2.94^{*}$ & $1.39^{\star \star}$ \\
\hline 人の気配 & 4.11 & 3.56 & $2.61^{* *}$ & $2.28^{* *}$ \\
\hline 監視性 & 2.33 & 2.5 & 2.67 & 2.78 \\
\hline \multicolumn{5}{|c|}{ 街路灯照度レベル（中） } \\
\hline & All off & $3 / 7$ on & All on & 電飾照明 \\
\hline 不安感 & 4.61 & $2.83^{* *}$ & $3.67^{*}$ & $1.89^{\star \star}$ \\
\hline 明るさ感 & 4.56 & $3.33^{* *}$ & 3.94 & $2.89^{* *}$ \\
\hline 人の気配 & 4.61 & $3.67^{*}$ & 4.33 & $2.67^{\star *}$ \\
\hline 監視性 & 3.5 & 3.11 & 3.44 & 2.83 \\
\hline \multicolumn{5}{|c|}{ 街路灯照度レベル（低） } \\
\hline & All off & $3 / 7$ on & All on & 電飾照明 \\
\hline 不安感 & 5.28 & 5.44 & $4.11^{\star \star}$ & $3.33^{\star \star}$ \\
\hline 明るさ感 & 5.5 & 5.17 & $4.61^{*}$ & $4.11^{\star *}$ \\
\hline 人の気配 & 6.39 & 6.56 & $5.06^{* \star}$ & $4.72^{\star \star}$ \\
\hline 監視性 & 4.11 & 4.17 & 3.72 & 3.5 \\
\hline
\end{tabular}

注) $* * \mathrm{p}<.01, * \mathrm{p}<.05$

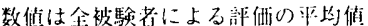

数倠のレンジは鼠大佰 7 最小倠 1 .

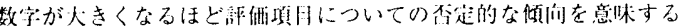


目は街路灯の照度レベルの高照度の条件と中照度の条件と同様に 【3/7 on】、【All on】、【電飾照明】のいずれの照明手法の場合にも有 意な違いは見られなかった。

以上の結果をまとめると、街路灯の照度レベルが高照度と. 低照度 の場合には、【All on】と【電飾照明】の照明手法を用いることで、 不安感を低減し、明るさ感を増大し、人の気配を感じさせることが 明らかになったが、【3/7 on】の照明手法については、有意差は見ら れなかった。一方で、街路灯の照度レベルが中照度の場合には、【3/ 7 on】と【電飾照明】の照明手法を用いることで、不安感を低減し、 明るさ感を増大し、人の気配を感じさせることが明らかになったが、 【All on】の照明手法については、不安感を改善する効果のみが有意 差を示した。同じく街路灯の照度レベルが中照度の条件のとき、上 記以外の関係に関しては有意な違いは見られなかった。

住民のパーソナリティに関する評価項目

表 3 に住民のパーソナリティを推測させることを求める質問項目 (“社交的である”、”家族の仲が良い”、”親しみがある”、”誠実で信 頼できる”、”独自性がある”)の実験結果を示す。先の環境に関する 評価項目と同様に、全 7 戸の住宅の門灯・立関灯が消灯している照 明手法【All off】を比較群として、次の 3 つの照明手法 (【3/7 on】、 【AlI on】、【電飾照明】）ごとの影響の違いを1元配置分散分析 (ANOVA)により検討した。表 2 と同じく、表中の数值は全被験者に よる評価の平均値を示し、数值が大きいほど評価項目についての否 定的な傾向を意味する。

街路灯の照度レベルが高照度の条件で、【3/7 on】の照明手法の場 合に”社交的である”と”親しみがある”の質問項目で危険水準 $1 \%$ で有意差があり、【All on】の照明手法の場合に”社交的である”の 質問項目で危険水準 5\%で有意差が示された。【電飾照明】の照明手 法の場合に”社交的である”、”家族の仲が良い”、”親しみがある”、” 誠実で信頼できる”、”独自性がある”の全質問項目で危険水準 $1 \%$ で有意差があった。

街路灯の照度レベルが中照度の条件で、【3/7 on】の照明手法の場 合に”社交的である”、”家族の仲が良い”、”親しみがある”、”誠実 で信頼できる”の質問項目で危険水準 $1 \%$ で有意差があり、”独自性 がある”の質問項目で危険水準 5\%で有意差が示された。電飾照明】 の照明手法の場合には街路灯の照度レベルが高照度の条件と同様に” 社交的である”、”家族の仲が良い”、”親しみがある”、”誠実で信頼 できる”、”独自性がある”の全質問項目で危険水準 $1 \%$ で有意差が あった。

街路灯の照度レベルが低照度の条件で、【電飾照明】の照明手法の 場合に”社交的である”、”家族の仲が良い”、”親しみがある”の質 問項目で危険水準 $1 \%$ で有意差があり、”誠実で信頼できる”の質問 項目で危険水準 5\%で有意差が示された。【3/7 on】と【All on】の 照明手法については、いずれも有意差が見られなかった。

以上より、街路灯の照度レベルに関わらず、【電飾照明】の照明手 法を用いることで、被験者に住民のパーソナリティを肯定的に推測 させる効果があることを示している。また、街路灯の照度レベルが 高照度と中照度の場合には、【3/7 on】の照明手法を用いることで、 被験者に住民のパーソナリティを肯定的に推測させる効果があるこ とが明らかになった。
表 3 住民のパーソナリティに関する評価項目に関する実験結果

\begin{tabular}{|c|c|c|c|c|}
\hline \multicolumn{5}{|c|}{ 街路灯照度レベル（高） } \\
\hline & All off & $3 / 7$ on & All on & 電飾照明 \\
\hline 社交的 & 4.50 & $3.28^{\star \star}$ & $3.72^{*}$ & $2.11^{\star \star}$ \\
\hline 家族の仲 & 3.89 & 3.28 & 3.50 & $2.61^{\star *}$ \\
\hline 親しみ & 4.44 & $3.17^{\star \star}$ & 3.72 & $2.61^{\star \star}$ \\
\hline 誠実・信頼 & 3.94 & 3.33 & 3.61 & $3.00^{* *}$ \\
\hline 独自性 & 3.89 & 4.17 & 3.78 & $2.67^{\star \star}$ \\
\hline \multicolumn{5}{|c|}{ 街路灯照度レベル（中） } \\
\hline & All off & $3 / 7$ on & All on & 電飾照明 \\
\hline 社交的 & 4.33 & $2.78^{\star \star}$ & 4.00 & $2.17^{\star \star}$ \\
\hline 家族の仲 & 4.11 & $3.00^{\star \star}$ & 4.00 & $1.94^{\star \star}$ \\
\hline 親しみ & 4.50 & $3.28^{\star \star}$ & 4.28 & $2.28^{* *}$ \\
\hline 誠実・信頼 & 4.11 & $3.17^{* \star}$ & 4.00 & $2.67^{* *}$ \\
\hline 独自性 & 4.39 & $3.56^{*}$ & 4.22 & $2.61^{* *}$ \\
\hline \multicolumn{5}{|c|}{ 街路灯照度レベル（低） } \\
\hline & All off & $3 / 7$ on & All on & 電飾照明 \\
\hline 社交的 & 4.28 & 4.28 & 4.11 & $2.83^{\star \star}$ \\
\hline 家族の仲 & 4.28 & 3.94 & 3.67 & $2.83^{* *}$ \\
\hline 親しみ & 4.83 & 4.39 & 4.06 & $2.78^{* *}$ \\
\hline 誠実・信頼 & 4.11 & 4.06 & 4.33 & $3.39^{*}$ \\
\hline 独自性 & 4.22 & 4.56 & 4.39 & 3.44 \\
\hline
\end{tabular}

酒) ${ }^{* *} \mathrm{p}<.01 . * \mathrm{p}<.05$

数做は全被験者による部㑣门平均值。

数做のレンジは最大值 7 一最小值 1

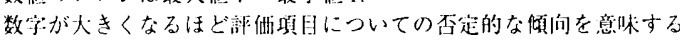

\section{4. 考察}

ここでは、こ机まで述べた実験結果を基に、まず、実験の結果と 直接関連する事項を考察し、次に、本研究の主題に関する今後の課 題について言及し、最後に、本研究の知見を実際的な照明計画に反 映させるための展望について議論する。

最初に、環境に関する評価項目の結果について検討する。街路灯 の照度レベルが高照度と低照度の場合には、【All on】と【電飾照明】 の照明手法を用いることで、不安感を低減し、明るさ感を増大し、 人の気配を感じさせる。街路灯の照度レベルが中照度の場合には、 【3/7 on】と【電飾照明】の照明手法を用いることにより、不安感を 低減し、明るさ感を増大し、人の気配を感じさせることが明らかに なった。電飾照明に関する検討は、後述するとして、まず、街路灯 の照度レベルが高照度と低照度の場合と街路灯の照度レベルが中照 度の場合で門灯や玄関灯の点灯数による上記の評価項目への影響に 違いが見受けられた理由について考察する。街路灯の照度レベルが 高照度であるように街路が比較的に明るいときには、門灯や玄関灯 が全て消された比較群の条件時において、街路灯の明るさにより環 境に関する評価は既に高くなっており、【3/7 on】のように門灯や玄 関灯の数が少々増加しても評価には影響せず、【All on】のように門 灯や立関灯を全て点灯する条件でようやく有意な影響を及ほしたと 考えられる。また、街路灯の照度レベルが低照度であるように街路 が比較的に暗いときには、街路灯の暗さにより環境に関する評価は 著しく低くなっており、【3/7 on】のように門灯や立関灯の数が少々 増加しても評価を好転させるだけの影響はなく、【All on】のように 門灯や玄関灯を全て点灯する条件ではじめて影響したと考えられる。 一方で、街路灯の照度レベルが中照度のときには、環境に関する評 価に対して街路灯の明るさによる影響がそれほど強くないと考えら 
れ、そのような条件の場合には、【3/7 on】のように門灯や立関灯の 数の少々増加した場合でも評価に有意な影響を及ぼしたと考えられ る。このことは、門灯や玄関灯による効果を最大限に生かすために は、街路灯の明るさレベルも同時に考慮に入れる必要があることを 示昖している。

電飾照明は、全ての街路灯の照度レベルにおいて、”監視性が高 い”以外の全ての環境に関する評価項目に対して非常に強い影響を 与えることが明らかになったここの理由については、電飾照明が多 数の小型高輝度の光源から構成しているため、輝き感田を感じやす く、今回使用した電飾照明が点滅タイプであったためにより誘目性 が高いことが考えられる。電飾照明を構成する光源の数量、点滅の 有無、設置方法などがどのような影響を与えるのかについては今後 の課題であろう。また、近年、わが国でもクリスマスの時節に電飾 照明を商業施設だけでなく個人の住宅に設ける事例が增えて掞り、 電飾照明を設置した住宅が多く見られる一部の住宅地では、その電 飾照明を钼光する目的で、多くの住民以外の人々を惹き付けている。 それに伴い、住民以外の人々による騒音やゴミの散乱などの問題も 顕在化している。このような電飾照明を設置することの負の側面に ついても検討しなければならない。

“監視性が高い”についての質問項目は、全ての街路灯の照度レ ベルで有意な違いは見られなかった。その解釈として、以下の二つ が考えられる。まず、門灯や立関灯の点灯している住宅数の増加は、 街路空間に扔いて人の気配を感じさせる効果があっても、環境の監 視性を高めるほどの効果はないと解釈できる。一方で、”監視性が高 い”という用語が多義的な解釈を可能にしているということである。 被験者が何かを監視するときの環境性能を示す評価項目なのか、被 験者自体が監視対象とした見られているような感じがする程度を示 すのかによって、微妙にニュアンスが異なってくる。また，監視性 が高い”という用語自体が日常生活上であまり聞き慣れない用語で あり、言葉の意味を理解することが難しいことが考えられる。この 用語の解积の曖昧さが原因として考えられる。どちらの理由による かについては、今回の研究の範囲では判断することはできず、今後 のさらなる検討が必要であろう。

さらに、住民のパーソナリティに関する評価項目の結果について 検討する。電飾照明は、街路灯の照度レベルに関わらず、被験者に 住民のパーソナリティを肯定的に推測させる効果があることを示し ている。この理由としては、環境に関する評価項目の場合と同様な 理由に加えて、電飾照明は、用途や目的を持たない娛楽としての私 的な光であることが住民のパーソナリティを肯定的に評価させたの ではないかと考えられる。また、門灯や玄関灯の点灯数とパーソナ リティの評価との関倸について、【3/7 on】のよに門灯や玄関灯の 点灯数が中程度の場合に、パーソナリティの評価に有意な影響を及 ほすが、逆に、全住宅の門灯や玄関灯が点灯してしまうと、門灯や 玄関灯が点灯することの効果が薄まることを示している。この結果 から、門灯や玄関灯の点灯数とパーソナリティの評価との関係は単 なる正相関ではなく、評価を極大化するような門灯や玄関灯の点灯 数の適正值が存在するかもしれない。さらに、この知見は玄関先に 植栽や個人所有物などを置くことが地域コミュニティにその住民の パーソナリティを表出することになることを明らかにした既往研究 18)199 と同様な効果を電飾照明の設置や門灯や玄関灯を点灯させるこ
とで得られる可能性を示唆している。

以上により、門灯、玄関灯、電飾照明などの私的領域からの光が 公的空間に打ける光環境評価と住民のパーソナリティ評価に有意に 影響するという研究仮説は支持されたと考えられる。さらに、住宅 地の街路空間の環境を向上させるためには、ただ単に街路灯を増設 もしくは改善することにより街路空間の照度レベルを高くするだけ ではなく、明るさ以外の側面での向上させること、それは、私的領 域にある門灯や立関灯を点灯させることによっても実現する可能性 を示唆している。加えて、門灯や玄関灯の効果を生かすためには、 街路灯による照度レベルも同時に考慮しなければならないことが明 らかになった。

本研究は、東京の郊外に所在する一住宅地における調査に基づい ているため、本研究で得られた知見がどの程度一般化できるかは明 らかではない。今後、住宅地の歴史、街路の形態、住宅地の周辺環 境等が異なる住宅地を用いた追加調査等を実施する予定である。ま た、先に述べた理由により住宅の悹から漏れ光を本研究の実験変数 から除外したが、私的領域の光環境による公的領域の光環境評価に

及ほす影響をより精緻に理解するためには、空からの漏れ光を含み 入れた検討も学術的には興味が尽きない。

最後に、本研究の知見を実際的な照明計画に反映させるための展 望について議論する。門灯や玄関灯は、街路灯を設置することが困 難な狭い街路空間においても比較的に容易に設置できるという長所 を有しているが、門灯や玄関灯自体は住民が個別に管理する照明で あり、門灯や立関灯をどのように設置し運用するかについては、門 灯や玄関灯の所有である住民の判断に委ねられている。本実験の終 了後に、実験に協力して頂いた住民に対して実施した著者らによる インタビュー調査によれば、住民の約 $80 \%$ 以上が、門灯や玄関灯 を点灯させる目的はその住民の家族のためであり、家族のメンバー が全員㷌宅したら門灯や玄関灯を消灯すると回答している。街路架 間における実際的な照明計画に、私的領域にある門灯や玄関灯を組 み込むためには、運営や管理に対するコストの負担や事故に対する リスクなどについて、住民と公的空間の管理者である行政との間で 合意を形成する必要がある。さらに、私的領域にある門灯や玄関灯 を公的空間のために提供することで、住民のプライバシーが侵害さ れる可能性もないとは言えない。このような公共の福祉と個人の権 利という社会的ジレンマ構造を視野に入れた研究も今後必要となる と考えられる。

参考文献

1）社团法人照明学会艑：ライティングハンドブック、オーム社、1987

2）日本工業規格 29110-1979（照度基集）

3）社咑法人照明学会・技術指針 JIEC - 001：オフィス照时基集、1992

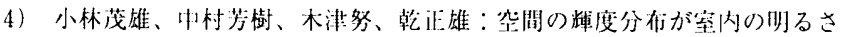
感に与之る影䇎、日本建築学会郭西系論文集、No.487、pp. 33-41、1996

5）小林茂雄、乾诖:雄、中村芳樹、北村麻子：公内環境照明の明るさ、均… と生活行為の関係、日本建築学会訫画系論文集、No.481、pp. 13-22、1996

6) 乾正雄：液は暗くてはいけないか、朝日新聞社、1998

7) 日本1:業規格 29111-1988（道路照四基準)

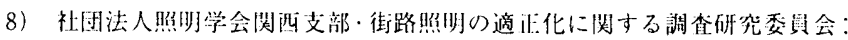
住宅地域における䏚犯照明の尖態、照明学:会誌、Vol.72、pp. 543-548、 1988

9）野口透:「街路·防犯照㽗」の調查研究活動について、警祭学諭集、Vol.47、 pp. 87-96、1994

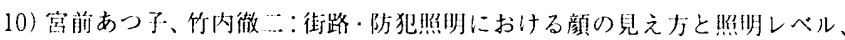
照明学会誌、Vol.74、pp. 303-307、1989 


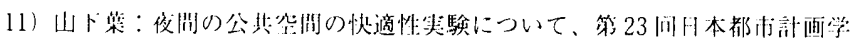
会学術研究淪文集、pp. 445-450、1988

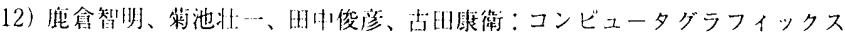

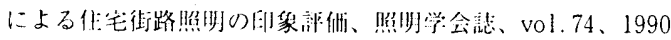

13) Newman, 0: Defensible Space; Crime Prevention through Urban Design, Macmill lan Pub., 1972

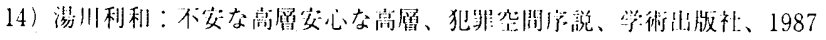

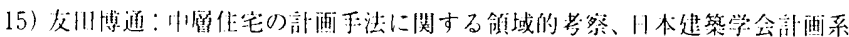
諭文教得集、Vol.365、pp. 121-131、1986

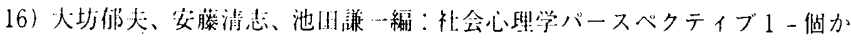
战他者一一、誠倍甚房、1989

17) Yukio Akashi, Izumi Akashi, Yoshinori Tanabe, and Sueko Kanaya: The sparkle effect of luminaires on the sensation of brightness, CIE119-1995-23rd Session. New Delhi, pp. 176-179, 1995

18）小林秀樹：集隹ひなわばり学、彰国社、1992

19) Clare Cooper Marcus and James Yandell: House As a Mirror of Self: Exploring the Deeper Meaning of Home, Conari Pr, 1997

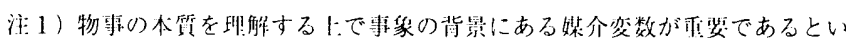

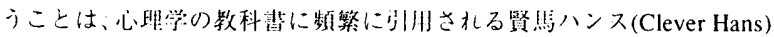

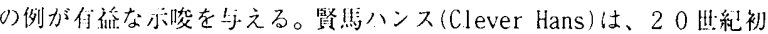

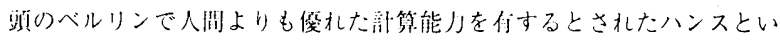

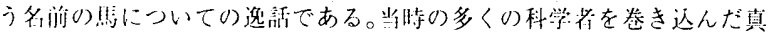

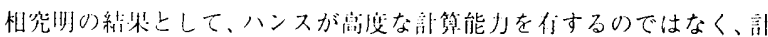

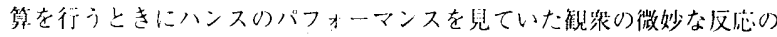
変化を媒介変数的に感じよることによりハンスは㤽解を幥き出してい た。

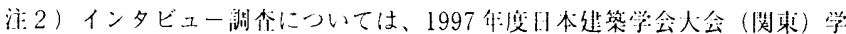

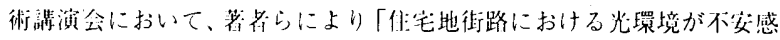

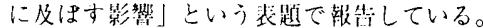

謝辞

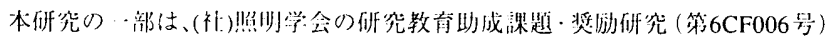
の援助のもとに策施さ机た。䛉して感謝の意を表します。

(1999年: 4 月10日原稿受理，1999年 9 月 9 日採用決定) 